Headley, S. A.', Saito, T. B. ${ }^{2}$, Bettini, C. M. ${ }^{3}$, Tomita, A. L. ${ }^{4}$

\title{
90 - Ocorrência simultânea de adenocarcinoma das glândulas ceruminosas e otite externa em um cão
}

1- Docente do Laboratório de Patologia Veterinária do Centro Universitário de Maringá (CESUMAR), Maringá-PR

2- Docente do Departamento de Clinica Médica e Terapêutica de Pequenos Animais, CESUMAR, Maringá-PR

3- Docente do Departamento de Radiologia e Clínica Médica de Pequenos Animais, CESUMAR, Maringá-PR

4. Médico Veterinário, Clinica Veterinária, ProntoDog, Maringá-PR.

O adenocarcinoma das glândulas ceruminosas da orelha externa é um tumor maligno que se apresenta como massas nodulares ou pedunculadas, de 1 a $2 \mathrm{~cm}$ de diâmetro. Muitas vezes, há crescimento tumoral resultando na obstrução parcial ou total do meato auditório externo. A otite externa é uma inflamação crônica ou aguda do canal auditiva externo causada pelas mudanças no microambiente normal da orelha. Esta inflamação é primária a agentes parasitários, doenças de hipersensibilidades, corpos estranhos, obstruçòes e doenças auto-imunes, e secundária a agentes bacterianos e fúngicos. Descreve-se a ocorrência simultânea de um adenocarcinoma das glândulas ceruminosas da orelha e otite externa em um cào. Um canino, Pastor Alemão, macho, 7 anos de idade, com histórico clínico de uma otite crônica associada a sangramento prolongado foi atendido no Hospital Veterinário, Centro Universitário de Maringá, Maringá, Paraná. Clinicamente, o animal demonstrou rotação lateral da cabeça para o lado da orelha esquerda, prurido intenso e uma secreção escura viscosa no canal auditivo. $\mathrm{Na}$ avaliação otoscópica da orelha esquerda, observou-se uma massa, nodular, de aproximadamente $1,5 \mathrm{~cm}$ de diâmetro, fixada à parede $\mathrm{e}$ invadindo o canal auditivo; cirurgia terapêutica se baseou na ablação parcial do canal auditivo e remoção total da massa. A massa tecidual retirada do canal auditivo externo demonstrou consistência firme, aspecto nodular com uma superficie parcialmente ulcerada; na superfície de corte, observaram-se pequenas áreas $(0,2-0,6 \mathrm{~cm}$ de diâmetro) com aspecto de couve-flor. A massa tecidual foi fixada em solução de formalina a $10 \%$ e processada para avaliaçào histopatológica de rotina. Na avaliação histopatológica observou-se epitelial superfície ulcerada e proliferaçào acentuada das células epiteliais na derme. Estas células apresentaram anaplasia, núcleos e nucléolos atípicos com muitas figuras mitóticas. As células neoplásicas foram dispostas em lençóis compactos, às vezes, invadindo o tecido conjuntivo adjacente. Muitas vezes as células neoplásicas formaram estruturas acinares moderadamente diferenciadas, de tamanhos diferentes, contendo acúmulo de secreção eosinofilica e homogênea. As manifestações clínicas e os achados patológicos encontrados neste animal são característicos de uma ocorrência simultânea de um adenocarcinoma das glândulas associada a uma otite externa. Neste caso, o animal apresentava manifestações clínicas da otite crônica antes do aparecimento tumor. Acredita-se que a inflamação crônica na orelha, o prurido intenso frente à agressão, a produção excessiva e conseqüente retenção de cera pelas glândulas apócrinas do ouvido externo e o sangramento intenso contribuiram para o desencadeamento do tumor. Casos de adenocarcinoma de glândulas ceruminosas que invadem o meato auditivo externo, como ocorre neste animal, geralmente apresentam a otite crônica como principal fator predisponente. Nos caninos, a maioria dos tumores originários das glândulas ceruminosas da orelha externa são benignos, a forma maligna não é muito freqüente. Entretanto, este animal apresentou a forma maligna do tumor; a apresentação maligna de tumores originários das glândulas ceruminosas geralmente tem prognóstico favorável quando o tumor for restrito ao canal auditivo. Neste caso, o tumor invadiu os tecidos moles adjacentes, porém recidivas não foram observadas desde a correção cirúrgica. 